\title{
Abhandlung
}

Charles W. Steitler*

\section{"Like an iron peg I have struck the words to the gods ...". A Hittite Invocation for Overturning Slander}

DOI 10.1515/za-2015-0016

Abstract: This article offers a full edition of a Middle Hittite invocation, CTH 389.2, addressed by the king to the Sun-god and the Storm-god especially, and known from four duplicate tablets in New Script. A recently identified adjoining fragment as well as numerous improved readings from the collation of photos and 3D scans of the tablets allow for significant advances in understanding this text, of which a central theme is the reversal of false accusations against the Hittite king.

\section{Introduction ${ }^{1}$}

The Hittite composition listed in the Catalogue des Textes Hittites as one of the "fragments of prayers", СTH 389.2, is an invocation spoken by a king who had become a victim of slander - apparently at the hand of his own subjects. The invocation was embedded within a ritual performed at the beginning of the month and possibly taking place over the course of two days. The text includes both assertions of the king's faithful performance of his cultic duties, as well as confessions of potential and perhaps also real transgressions. An appeal to the special relationship which exists between the king and his gods undergirds the weight of the invocation. The king invokes these gods to ignore the slander which various persons had committed against him. In addition to some well-known topoi from other Hittite religious texts, a few literary themes also occur which are unique to this particular composition.

1 The author would like to express his thanks to Daniel Schwemer and Michele Cammarosano for reading earlier versions of this article and offering numerous corrections and suggestions for its improvement. The responsibility for any mistakes lies solely with the present author. Abbreviations follow those of the Chicago Hittite Dictionary.

*Corresponding author: Charles W. Steitler, Hethitisches Wörterbuch, Institut für Assyriologie und Hethitologie, Ludwig-MaximiliansUniversität, München; Email: csteitler@lmu.de.

\section{Previous Studies}

The text composition of CTH 389.2 has traditionally been assigned to the genre of prayer. Singer (2002a, 21-28) includes an excellent translation of it in his anthology of Hittite prayers alongside two other invocations which he believed to represent an early stage of the evolution of this text genre (see also Singer 2002b, 304). The indirect join between two of the fragments of ms. A (KUB 36.91 (+) KUB 43.68) was published by Otten/Rüster (1974, 243f.) with a partial transliteration of the text also reflecting the duplicates known at the time. The edition of these two fragments by Lebrun (1980, 392-396) is of limited value, since, although aware of the indirect join, he nevertheless presents these fragments separately, and makes no attempt to reconstruct the full lines of this portion of the tablet. Since then, in 2012, J. Lorenz identified KUB 43.71 as a bridge join between the other two fragments of ms. A, which neither Lebrun's edition nor Singer's translation accounted for. This additional fragment provides a substantial amount of new context, also unknown in the duplicates, and thus enables a much more complete text reconstruction than was hitherto possible. Furthermore, thanks to collations of photos of fragments of all four duplicates, ${ }^{2}$ as well as 3D

2 Online photos of the fragments of the Mainzer Photoarchiv were accessed through the Hethitologie Portal Mainz (www.hethport. uni-wuerzburg.de). 
scans of the fragments of ms. $A,{ }^{3}$ a number of new readings and text restorations are now possible. This allows for a significantly improved and expanded understanding of this invocation, despite the fact that extensive sections still remain fragmentary. These circumstances more than justify a new full edition of CTH 389.2 with philological commentary, as presented in this article.

\section{Structure}

Although Singer (2002a, 24) correctly notes that this invocation begins with a description of "ritual preparations" (referring to 11. 1-12), ${ }^{4}$ the present author understands the details of the ritual setting to be limited to $11.1-5$, whereas the cultic activities referred to in $11.6-12$ actually belong to the invocation proper and form an important part of the supplicant's self-justification. Surprisingly, however, the division between this brief description of the ritual setting and the invocation itself is not clearly marked with a specification of the speaker and the moment in the course of the ritual when the invocation was spoken, as is often the case when the wording of an invocation is included in a ritual text. We can conclude, at least from 11.4 and 62 , that the ritual would have been performed at the beginning of the month, and 1.44 seems to suggest that the ritual lasted for at least two days. Following this minimal information concerning the ritual context, the text segues seamlessly to a more universal description of the king's faithfulness and diligence in carrying out his cultic responsibilities (§2). Subsequently, however, the invocation suggests a confession of the king's own potential sins or perhaps of the sins of another member of the royal household (§§3-4).

The king describes his special relationship to the gods, ( $\$ 5)$, and clearly attributes the legitimation of his rulership to the authority which the gods had bestowed

3 The 3D scans of KUB 36.91 (Bo 6496), KUB 43.71 (Bo 798) and KUB 43.68 (Bo 7288) were carried out in Istanbul in the Archaeological Museum by the project "3D-Joins und Schriftmetrologie" (Julius-Maximilians-Universität Würzburg, Technische Universität Dortmund, Akademie der Wissenschaften und der Literatur, Mainz; see www.cuneiform.de as well as Fisseler et al. 2014), under the direction of Gerfrid G. W. Müller, whom I thank for permission to make use of the scans for collation of ms. A. My thanks are also due to Michele Cammarosano for his technical assistance in accessing the scans in Würzburg.

4 Unless otherwise noted, references to lines of the text of CTH 389.2 follow the line numbering of the master text, indicated by the bold numbers in the transliteration as well as the transcription presented below. upon him (§6). At this point, the invocation begins to identify the source of the king's sufferings in the evil accusations and curses brought against him by his own subjects (§§ 7-9). The fragmentary text seems to imply that the king's(?) son (DUMU, i.e. the [crown?] prince) had also been suffering $(\S 10)$ and requests the gods' benevolence upon him as well.

The invocation reaches its climax in beseeching the Sun-god and the Storm-god to look upon the king and queen with "kind eyes" in order to sustain them (§11). Furthermore, the king requests that the curses and accusations against him be turned back upon those with whom they originated, while he himself should be spared. Here especially, the text composition makes use of highly poetic language, expressing these wishes in terms of similes (§§ 11-12).

\section{Literary Themes and Devices}

A number of topoi known from other Hittite prayers as well as from ancient Near Eastern literature in general appear in this text. However, some of the motifs are unique to this invocation and thus provide us with a glimpse of otherwise unknown ancient literary traditions.

In $\S \S 2$ and 6 we find the self-justification of the supplicant, who is clearly identified as the king. He pleads his case before the gods by claiming to have devoted himself to their cults and to have presented appropriate offerings to them. The prayer even seems to allude to the king's own contributions to the agricultural labor necessary for cultivating the crops (ll. 7-9) used to produce these offerings (wine, meal and bread). At the same time, the king does not rule out the possibility of his own guilt or of that of a member of his household, the consequences of which he himself was also required to bear (§3). ${ }^{5}$ Indeed, the (albeit fragmentary) remains of the text appear to contain at least one such confession of the king's own guilt (1. 15); whether this confession was real or merely pro forma cannot be determined with certainty. Singer (2002a, 10) has already pointed out the seemingly paradoxical juxtaposition of self-justification and confession of sin before the gods in the Hittite prayers in general.

5 This concept is expressed very well in Muršili’s Second Plague Prayer, KUB 14.8 rev. 11-14: "My father sinned as well and he transgressed the word of the Storm-god of Hatti, my lord. But I did not sin in any way. Nevertheless, it so happens that the father's sin comes upon his son, and so the sin of my father came upon me too" (translation according to Singer 2002a, 59). 
In any case, this invocation makes it very clear that the primary source of the king's suffering were the unjust accusations and curses brought against him: $\S \S 6-9$ and $\S \S 11-12$ all address this subject in some form or another. A variety of terms are used to express the concept of slander and cursing, including bringing evil (accusations) against someone (idālu uda-, §11), cutting someone off (kurešk-, $\S 7$ ), cursing (hūrzak-, §7), the evil tongue (idalu- lala-, §7), the words of that which is cut up? (kukkuraškantaš uddār, §9), the words of that which is cut off (karšandaš uddār, $\S 9$ ), and the evil word (idālu uddar, §§11-12).

The well-known topos of the orphan to whom the gods alone are mother and father occurs in $\S 5$; the topos is also found in the three parallel prayers to the Sun-god (CTH 372-374) which are modeled after Mesopotamian text compositions. ${ }^{6}$ The gods are then compared to the king, who in turn likens himself to his own subjects. The king's attribution of his royal authority to the gods (1l. $24 \mathrm{f}$.) echoes the passage of an $\mathrm{OH}$ foundation ritual, KUB $29.1 \mathrm{i} 17 \mathrm{f}$., 24 f. (CTH 414.1, see Görke 2012b, TX 18. 06. 2012, TRde 18. 06. 2012; Kellerman 1980, 11. 25).

The simile of the rear wheel which never catches up with the front wheel (§12) also occurs in the Ritual of Hantitaššu (see Miller 2004, 451; Ünal 1996, 20 f.), whereas the simile of the snake which does not miss its hole $(\S 11)$ is unique to the present text. Snake imagery, however, does occur in other Hittite texts, e.g. in the Hittite Laws $§ 170,{ }^{7}$ where the snake is associated with what appears to be a form of witchcraft. ${ }^{8}$ Another simile in this text (ll. $61 \mathrm{f}$.) likens the words of the prayer to an iron peg, recalling the analogical magical rite of pounding a peg into the earth in order to reverse the effects of slander, witchcraft or some other evil. ${ }^{9}$ In the same way, the supplicant hopes

6 In CTH 372:175 ff., CTH 373:54'f. and CTH 374:83"fff. (line numbering according to the most recent edition of these texts by Schwemer in press). On the relationship of these prayers to the DINGIR.ŠÀ.DIB.BA incantations, see Güterbock (1974), and to the Sumerian text "Utu the Hero”, see Metcalf (2011).

7 The law is as follows: "If a free man kills a snake, and speaks another's name, he shall pay one mina (i.e. 40 shekels) of silver. If it is a slave, he himself shall be put to death" (translation by Hoffner 1997, 136).

8 According to Hoffner (1963, 284f.), this represents a case of sympathetic magic intended to harm the man whose name was spoken. Haas (2003, vol. 1, 474-476) considers snakes to have been a metaphor for "schädigende Kräfte", for example, the Political Testament of Hattušili I compares Tawananna with a snake (KUB 1.16 ii 10, 20; see Collins 1989, 214 f.); see also Singer (2002a, 24).

9 Ritually striking a peg into the ground may have an apotropaic effect, as is the case in the foundation ritual, KBo. 4.1+ obv. $5 \mathrm{ff}$. (see Görke 2012a, TX 04. 06. 2012, TRde 23. 02. 2012; Kellerman 1980, $126 \mathrm{f} ., 134)$. On the other hand, in the Ritual of Maštigga (see Miller 2004, 94 f.; Mouton 2012, TX 07. 05. 2012, TRfr 21. 03. 2012), the peg to "pound in" the words of his prayer like a peg in order to undo the curses which had been brought against him. This particular simile is also unique to the present text.

\section{Identification of Deities and Relationship to Other Text Genres}

Although the prayer frequently addresses or makes reference to the gods in general, the Sun-god and the Stormgod are specifically invoked in 11.51 and 53. Furthermore, the text specifies that the false accusations against the king were brought before the Sun-god and the Storm-god. Our identification of the solar deity in this invocation as the male Sun-god requires a more detailed explanation, ${ }^{10}$ which will be briefly summed up here in connection with a discussion of the relationship of this invocation to some other Hittite texts. The simple logogram, ${ }^{\mathrm{U}} \mathrm{UTU}$, does not in itself indicate which of the several different solar deities of the heterogeneous Hittite religious tradition is being referred to in this text. The core structure of the Hittite state pantheon - especially as it is reflected in the festival texts, for example - appears to have retained substantial elements of the Hattian pantheon. This is reflected by the Hattian names of many deities, as well the occurrence of Hattian recitations in connection with certain deities. Already at the outset or in the course of the early Hittite kingdom, the Sun-goddess (frequently accompanied by the ancillary goddess Mezzulla) and the Storm-god were established as the supreme deities of the Hittite state pantheon. This pair of deities appears to have had a significant function as the divine benefactors of the king especially and of the royal family in general.

Simultaneously, however, many of the texts belonging to the mythological-magical tradition of the Hittites can be attributed to a tradition which stood in close proximity to the Luwian religious milieu. There, for example, we find the recurrence of the Sun-god Tiwad alongside the goddess Kamrušepa. In the mythological tradition surrounding Telipinu, it can also be argued that the solar deity was a male Sun-god, and that he and his brother Telipinu were considered sons of the Storm-god. It thus stands to reason that the solar deity who hosts the feast for the gods in the various permutations of the disappearing deity myth was also a male Sun-god.

represents the quarrelsome words which have been spoken, and are negated through the act of striking the peg into the ground.

10 For an extensive treatment, see Steitler 2014. 
This Sun-god - although not the supreme deity in the pantheon - was, nevertheless, an especially high-ranking deity whose competencies included the oversight of the divine assembly. Since he was conceived of as occupying a particularly advantageous position among the gods from which to defend and acquit the ritual patron, the Sun-god would have been a suitable addressee of those magical rituals typically aimed at removing guilt and impurity from the ritual patron. Implicit to this scenario is the Sungod's role as the defender of justice; this included combating false allegations in a legal context. The association of the Sun-god with the Storm-god may have originated in Syrian or (upper) Mesopotamian religious traditions, which made their way to Anatolia already in the early $2^{\text {nd }}$ millennium BC. Alternatively, this nexus might instead have been the result of inner-Anatolian religious contemplations which attributed a synergetic function to these two very significant Anatolian deities. ${ }^{11}$ The view that this invocation was not addressed to the (Hattian) Sun-goddess, the spouse of the Storm-god, is supported by the fact that a comparable ritual against slander performed for Tuthaliya and Nikkalmati was addressed to the "Sun-god of blood" - an epithet connoting the conception of bloodguilt, in this case, the unjust accusations brought against the royal couple. Such a ritual should be considered part of the Hittite magical-mythological tradition, and one would thus expect its solar deity to correspond to the Sun-god prominent in that same tradition, whose profile we briefly outlined above. This also applies to the solar deity invoked alongside the Storm-god in the text of CTH 389.2. Of those prayers which do clearly address the Sun-godddess (of Arinna), sometimes together with the Storm-god, it can be said that they either explicitly emphasize the role of this goddess/of these two deities as patrons of the Hittite king, or that they are intended to exculpate the king of guilt already incurred upon the royal office in preceding generations. The latter scenario, however, differs significantly from the "evil tongues" and "cursing" of the present text: these wrongdoings were current and ongoing when the invocation was originally composed and/or performed, and apparently also at the time of the redaction of this text in the Empire period (see below on the historical setting and dating of this composition).

11 Although Taracha $(2013,376)$, claims that the Sun-god and the Storm-god side by side first occurred as the "Deities of Kingship par excellence" in the early Empire period, the present author would argue that the prominent role of the male Sun-god within Hittite religion can be traced back to earlier Anatolian traditions, as are reflected in the Luwian, Palaean and Kanešian panthea, which were already present in the Hittite Old Kingdom and probably already in the Old Assyrian period as well (see Steitler 2014).
The collocation of the Sun-god and the Storm-god, references to evil tongues and slander directed against the king, as well as the association of this prayer with a ritual context justify our comparison of it with the aforementioned Ritual of Tuthaliya and Nikkalmati (CTH 443; see recent editions by Kassian 2000, and Görke 2006). The latter ritual was performed for the conciliation of the Sun-god of blood and the Storm-god, and was specifically aimed at reversing the effects of slander caused by Ziplantawiya. The ritual utilizes physical models of evil tongues representing slander and curses, which are then rendered innocuous during the course of the ritual. The fact that CTH 443, like CTH 389.2, also makes reference to members of the royal family provides yet a further point of comparison between the two texts.

Finally, the text of CTH 389.2 calls upon the gods as witnesses and makes mention of a seal, probably employed to affirm the invocation's weight and authenticity $(\S 12)$; these are not typical elements of prayers, but they would be expected in a treaty or an oath text. From this standpoint, CTH 389.2 can also be compared with the prayer of Arnuwanda and Ašmunikal (CTH 375.1; see Singer 2002a, 40-43), a composition which combines elements of both prayers and oaths (see Hutter 2012, 666; Klinger 2005, 350-355; Neu 1983, 392; von Schuler 1965, 164).

\section{Historical Setting}

The contents of CTH 389.2 imply that at the time of its composition, the Hittite kingdom was in a state of political turmoil. Strife within the royal family is suggested by the statement that transgression had entered into the king's house (1. 14), and perhaps also by references to members of the royal family (brother: 1. 21; wives: 1. 40). The text also hints at some kind of socio-economic upheaval when the king states that his subjects curse him from behind the millstone and from underneath their "burden" (11. 29-30). This could be taken to mean that the state had imposed an undue workload upon the population - a claim, however, which the king immediately denies in the invocation (1.31). The intercession made specifically for the prince in $\S 10$ might indicate that he as well had been subjected to some sort of anguish. Unfortunately, the aforementioned passages are all either too vague or too fragmentary to be able to contextualize them within any specific historical circumstances known to us from the Hittite kingdom. However, the language of at least some sections of this composition must be characterized as Middle Hittite or, possibly (though not necessarily), earlier (see below). This 
reflects a process of textual redaction utilizing compositions from an earlier period of the Hittite kingdom which still retained their significance during the Empire period..$^{12}$

\section{Dating the Language of the Composition}

Numerous features of the language within this composition suggest its origin in a period antedating the extant tablets on which it is presently preserved. The text bears numerous grammatical, lexical and orthographical trademarks of Middle Hittite ( $\mathrm{MH}$ ) especially, and to a lesser degree of Old Hittite (OH). Grammatically, the case morphology points to the text's MH or earlier origin. This is highlighted particularly by those instances where both the possessive pronominal suffix as well as the noun to which it is attached show the proper declination. ${ }^{13}$ Since in New Hittite (NH) the function of the instrumental case is increasingly taken over by the ablative, the former's occurrence in 11.17 (uddanit) and 54 (šakuit) should also be noted as a potential $\mathrm{MH}$ feature. Of especial interest are the nominal sentences in the first and second person, none of which, however, are constructed with reflexive $-z a$ or an enclitic reflexive pronoun. ${ }^{14}$ This would have been obligatory for first and second person nominal sentences in $\mathrm{NH}$, and can already be found in $\mathrm{MH}$ (see Hoffner/ Melchert 2008, 362f.). Therefore, these represent at least $\mathrm{MH}$ (or earlier) nominal sentence constructions. Older lexical features include the use of the conjunction takku (1. 15) which most frequently appears in $\mathrm{OH}$ texts (see Hoffner/Melchert 2008, 392), especially the collection of Hittite laws, and in NS copies of older ( $\mathrm{MH}$ and $\mathrm{OH}$ ) compositions. Some words, frequently written with logograms in younger Hittite texts, occur in this composition in syallabic writings instead (mahhan: 11. 4, 57, 59, 69; appanda: 1. 33) - also a feature of older Hittite texts.

Simultaneously, this composition also contains some features of $\mathrm{NH}$ texts, such as the use of logograms ${ }^{15}$ and the occurrence of the conjunction - ma following a conso-

12 For a similar phenomenon with regard to the Empire period prayers modeled after $\mathrm{MH}$ prayers to the Sun-goddess of Arinna, see van den Hout (2007, 407-409) as well as Schwemer (2006, 239-241). 13 Especially noteworthy are the following nouns with pronominal suffixes: waštauš=muš (pl. acc. com., ll. 16, 19), ki[šs $]$ ari=mi (sg. dat.-

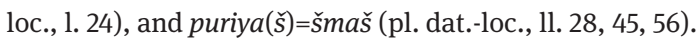

14 Examples of sg. 1 nominal sentences occur in 11. 7, 10, 11 and possibly 12; 1.22 contains two pl. 2 nominal sentences.

15 I-NA (1. 14); ك̌A-PAL (1. 29, 40); EGIR(-pa) (1. 30, 58); Ú-UL (1. 25, 58, 60). nant. ${ }^{16}$ The writing of the pres. sg. 3 of wemiya- in 1.60 (B rev. 13: ú-e-mi-ia-az-z[i) is distinctive of $\mathrm{MH}$ and $\mathrm{NH}$ texts, whereas in OS texts it is frequently written as ú-emi-ez-zi (see Kloekhorst 2008, 998); the relevant passage (§12) also occurs in a $\mathrm{MH}$ ritual. ${ }^{17}$ The text in general gives the impression of a $\mathrm{MH}$ composition whose language was updated on some points, but remained archaic on many others. There does not, however, appear to be any indisputable evidence for an $\mathrm{OH}$ dating of this composition, although this cannot be definitively ruled out. Nevertheless, it seems more prudent to consider CTH 389.2 a MH composition which was redacted in the Hittite Empire period, resulting in four duplicate NS tablets - to our present knowledge, the only extant witnesses of this composition.

\section{Description of the Tablets and History of Transmission}

All four manuscripts are written in NS, and as far as can be ascertained, all are single-columned tablets inscribed on both sides.

$\begin{array}{llll} & \text { Publication } & \text { Inv. Nr. } & \text { Find Spot } \\ \text { A } & \text { KUB 36.91 + } & \text { Bo 6496 } & - \\ & \text { KUB 43.71 + } & \text { Bo 798 } & - \\ & \text { KUB 43.68 } & \text { Bo 7288 } & - \\ \text { B } & \text { KUB 60.156 } & \text { Bo 2477 } & - \\ \text { C } & \text { KBo 59.5 } & 871 / z & \text { T.I } \\ \text { D } & \text { KBo 55.27 } & 702 / z & \text { T.I }\end{array}$

Of the four known manuscripts, ms. A preserves the largest amount of text, with 28 lines on the obv. and 23 lines on the rev. The upper section of the tablet, which would have borne approximately 10 lines of texts (based on a reconstruction according to ms. B), is missing. Ms. A provides an uninterrupted, but still fragmentary, continuation of the text, where mss. B obv. and C obv. both break off before continuing on the rev. The bridge join formed by KUB 43.71 allows for an almost complete restoration of the text in $\mathrm{A}$ obv. 11-15 and rev. 13-15. Just as importantly, KUB 43.71 preserves the lower edge of the tablet with the final lines of the obv. and the first lines of the rev. Thus, despite the gaps at

$16 u k=m a$ in 1. 51; in a MH text, one could very well have expected $u g=a$, whereas $u k=m a$ is distinctively $\mathrm{NH}$ (see Hoffner/Melchert 2008, 395).

17 In the Ritual of Huantitaššu, KBo 11.14 ii 22-24 (MH/NS, see Ünal 1996, $20 \mathrm{f}$. 29); there, we find the writing ú-e-mi-ia-zi, which is also well-attested in MS and later texts. 
the beginning and end of the lines, the preserved text provides at least a general sense of the overall contents of this section of the composition, which is otherwise completely unattested. Furthermore, thanks to KUB 43.71, the total amount of text on this tablet can be secured with certainty, since ms. B preserves the beginning of the composition, the text of which continues uninterrupted in ms. A from the obv. to the rev., and again on the rev. of ms. B, which preserves the lower edge of the tablet. The final lines of the tablet are also preserved in ms. C. It is possible that a colophon might have followed the final lines of the rev. of ms. A; the preserved surface following the final paragraph marker is uninscribed, but sufficient space is available below and to the left of this area to have accomodated a colophon.

The only manuscript which preserves the first lines of the tablet or a colophon is ms B. This tablet's obv. contains
16 lines of text, the rev. (including the lower edge) 21 lines and 1.64 as well as the colophon were inscribed on the tablet's left edge. Judging from the amount of text in ms. A, ms. B preserves only about half of the complete text of the tablet, so that it originally must have contained a total of ca. 80 lines of text.

Portions of only 24 lines are preserved by ms. C. The distribution of the text on this fragment suggests that the lines in ms. C were slightly shorter than those in ms. A, but yet longer than in ms. B; thus, we estimate that the text was distributed in a total of ca. 70 lines on this tablet.

The smallest duplicate, ms. D, contains only 8 fragmentary lines of text, from which no certain conclusions can be drawn about the tablet's size or of the number of lines on it.

\section{Text Distribution}

\begin{tabular}{llllll}
\hline$\S$ & Master Text & A & B & C & D \\
\hline$\S 1$ & $1-5$ & & obv. 1-5 & & \\
$\S 2$ & $6-12$ & & $6-12$ & & $1-7$ \\
$\S 3$ & $13-16$ & obv. 1-3 & $13-16$ & obv. 1-4 & 8 \\
$\S 4$ & $17-19$ & $4-6$ & 17 & $5-7$ & \\
$\S 5$ & $20-23$ & $7-10$ & & $8-10$ & \\
$\S 6$ & $24-28$ & $11-15$ & & & \\
$\S 7$ & $29-41$ & $16-28$ & & & \\
$\S 8$ & $42-46$ & rev. 1-5 & & & \\
$\S 9$ & $47-49$ & $6-8$ & & rev. 1 & \\
$\S 10$ & $50-52$ & $9-11$ & rev. 1-3 & $2-8$ & \\
$\S 11$ & $53-58$ & $12-17$ & $4-11$ & $12-19$, lo.e. 1-2 & $9-14$ \\
$\S 12$ & $59-65$ & $18-23$ & le.e. 2 & & \\
Colophon & 66 & & & & \\
\hline
\end{tabular}

\section{Transliteration}

\section{§ 1}

\begin{tabular}{|c|c|}
\hline B obv. 1 & {$\left[\begin{array}{ll}\mathrm{x} & \mathrm{x}\end{array}\right]$-ša-[${ }^{\top} a n$ LUGAL-uš ša-ra-a ${ }^{1}[$} \\
\hline B obv. 2 & {$\left[\begin{array}{ll}\mathrm{x} & \mathrm{x}\end{array}\right]-n a$ pa-iš ez-za-aš-te-Гen ${ }^{\top}[$} \\
\hline B obv. 3 & 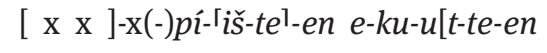 \\
\hline B obv. 4 & [ma-a]h-ha-an-ma ITU.GIBIL ti-[ia-zi \\
\hline $\begin{array}{l}\text { B obv. } 5 \\
\text { B, D }\end{array}$ & {$\left[\mathrm{x}\right.$ ]-Г${ }^{\top} w a{ }^{1}-a s ̌$ e-eš-ša-ri-iš-šs $[i-i t$} \\
\hline
\end{tabular}

\section{§ 2}

6 B obv. 6

[k]u-wa-at-I kán ${ }^{1}$ DINGIR ${ }^{\text {MEŠs }-e s ̌ ~ L U G A[L-u s ̌ ~}$

D: $1^{\prime}$

-ká]n

DINGIR $^{\text {MEŠ }}$-iš LUGAL- $u \check{s}$ 「 $t i^{1}-[$ 
7 B obv. 7 ta-ri-ia-an-za-aš- $\left.{ }^{-} m i\right]-i s ̌ ~ u ́-u[k$

D: 2' ta-ri-ia-a]n-za-aš-mi-iš ú-uk GIš x ${ }^{\prime} \hat{u}^{1}[$

8 B obv. 8 kar-pa-an har-mi GIšiš-hna-u-w[a-ar-ša-mi-it

D: 3' h] $\quad$ ar-mi GIšiš-ḩa-u-wa-ar-ša-mi-i[t

9 B obv. 9 ú-uk har-mi mi-ma-al-[̌̌ ${ }^{1}-m i-i[t$

D: 4' me-m]a-al-ša-mi-it iš-pa-an-t[u-

10 B obv. 10 an-「ni-iš-ki'-mi A-NA DINGIR MEŠ $n[a-a h$-h̆a-an-za ú-uk

D: $\left.5^{\prime} \quad A-N\right] A$ DINGIR ${ }^{M E S ̌ ~} n a-a h-h a-a-a n-z a$ ú-u[k

11 B obv. 11 「ta-ril-ia-an-za ú-uk nu me-ma-a[l

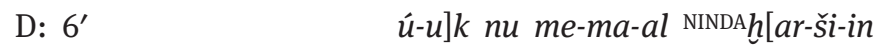

12 B obv. 12 「iš`-pa-an-tu-uz-zi-aš ta-ri-「ia $1-[a n-z a$ ú-uk

D: $7^{\prime}$

] ú-uk [

$\mathrm{A}, \mathrm{B}, \mathrm{D}$

\section{§ 3}

13 A obv. $1^{\prime}$

B obv. 13

C obv. 1'

D: $8^{\prime}$

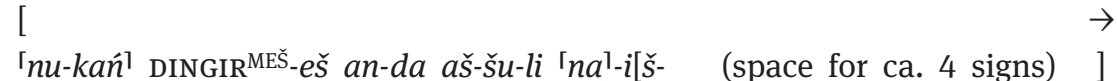

] ]

14 A obv. $1^{\prime}-2^{\prime}$

] $\mathrm{x}[$



15 A obv. $2^{\prime}-3^{\prime}$

B obv. 15

C obv. $3^{\prime}$

wa-aš-ta-a]h-hu-un / [

[x] x [har?]-ni-in-kán-za wa-aš-ta-ah-huu-un ták-ku 'a $a^{1}-\mathrm{x}[$

$w a-a s ̌-t a-a] h-\left[h u^{1}-u n\right.$

16 A obv. 3'

B obv. 16

C obv. 4'

「wa??-aš??-ta??-ah?-hu-un' [(x)] nu wa-aš-ta-uš-mu-uš [

] $\mathrm{x}-\mathrm{še}^{?}$ e-eš-ta

B

\section{§ 4}

17

$\left.\begin{array}{ll}\text { A obv. } 4^{\prime} & {[} \\ \text { B obv. } 17 & {[}\end{array}\right] \times[$

]x-te-et ud-da-ni-i-it

C obv. $5^{\prime}$

$x[$

] $e$-eš-ta

18 A obv. 5'

C obv. $6^{\prime}$

]x LÚGAL me-mi-ia-na-az

]x-a-iš

19 A obv. 6'

C obv. $7^{\prime}$

C obv. 7'a

] DINGIR ${ }^{\mathrm{MES}}$-iš $w a-a \check{s}^{-}{ }^{\top} t a-u \check{S}^{-} m u^{1}-u s ̌$ har-ni-ik-tén

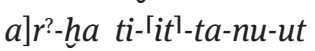

] (uninscribed)

A, C 


\section{§ 5}

20
A obv. 7' [ ] x x [ ] x [
(ca. 8-10 signs)
C obv. $8^{\prime}$

]$(-)\left\lceil e^{1}-e z-z i\right.$

$(-) e-e z-z] i$

21 A obv. 8' [ 8 $^{\prime}$ x $\left.-n\right] a$ ŠEŠ-ŠU 'mu-un'-[na-? nu-mu A-BU-IA] NU.GÁL nu-mu AMA-IA ${ }^{\lceil}$NU.GÁL ${ }^{\top}$

C obv. 9' [ ]x *NU.GÁL $\mathrm{X}^{\star}$

22
A obv. 9'
「nu-mu` šu-meš DINGIR ${ }^{\mathrm{MES}}$-iš $A-B\left[U-I A^{2}\right.$
(ca. 8 signs)
$A M A]-I A /-y a ? d \mathrm{UTU}$ ŠI $\check{s} u-m e \check{~}$
C obv. 10'
[
š] $u-{ }^{[} m e \check{s}^{1}$

23
A obv. $10^{\prime}$
$\hat{u}-u k-k a_{4} \mathrm{I}^{\mathrm{MES}}{ }_{-}-K U-N U$
]
ú-uk

A obv.

\section{§ 6}

24 A obv. 11'

nu-mu šu-meš-pát DINGIR ${ }^{\mathrm{MEŠ}}$ LUGAL-UT-[TI] 「ki?1-[išs-š] $a-r i-m i$ da-a-iš-tén

C obv. $12^{\prime}$

[

]x

25 A obv. 12'

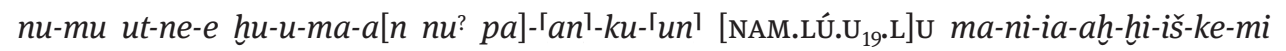

A obv. 13'

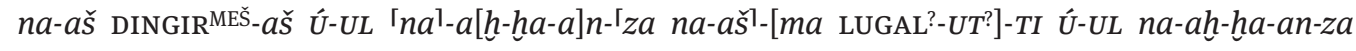

A obv. $14^{\prime}$

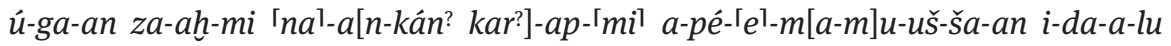

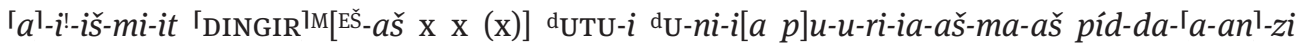

A

\section{\$ 7}

29 A obv. 16'

[na?-a]n ku-re-eš-kán-z[i (ca. 5 signs) ]-kán-zi ìn ${ }^{\mathrm{MEŠ}}-m u$ [š $] A-P A L$ GUN!

30 A obv. 17'

[hu-u-u]r?-זza?-kán-zi [

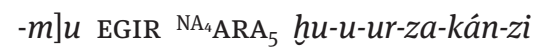

31 A obv. 18'

[ (ca. 4 signs)] x [ (ca. 6-7 signs) ]-ša le-e iš-ta-ma-aš-te-ni du-ud-du 「d?][(x)]

32 A obv. 19'

33 A obv. 20'

[ (ca. 8 signs) le-e iš?-š] $a$ ?-at-te-e-ni nu-「ušl-ma-aš-[kán x LUGAL?-i?] [ $\mathrm{x} \times 1$

(ca. 10 signs)

A obv. $21^{\prime}$

A obv. 22'

A obv. 23'

A obv. $24^{\prime}$

A obv. $25^{\prime}$

A obv. 26'

40 A obv. $27^{\prime}$

41 A obv. 28'

A obv.

\section{§ 8}

42 A rev. 1

43 A rev. 2

44 A rev. 3

45 A rev. 4

46 A rev. 5

A rev.

\section{§9}

47 A rev. 6

-a]r? ku-Гuk'-kur-aš-kán-ta-aš ud-「da1-[a?-ar

48 A rev. 7

G]İ̀-an kar-ša-an-da-aš ud-d[a-a?-ar

i-da-lu?]-un EME-an le-e iš-t[a-ma-aš-te-ni(?)

l]e-e iš-ša-at-te-ni me-[ (ca. 8 signs) ]

]x LI-IM wa-aš-ta-aš ku-iš [

]x mu-un-na-eš-ket $t_{9}$-te-ni ${ }^{*} n u^{*}-u\left[\check{s}^{\text {? }}\right]$

t]i-ia-an-ni-eš-ket, ${ }_{9}$-te-ni ki-nu- ${ }^{-} n a^{1}$ [ ] ]

]x na-at mu-un-na-at-tén x [

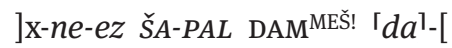

ha]r-ni-ik-tén

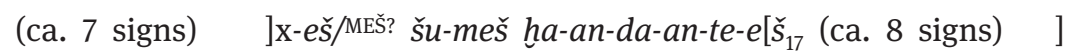
$u]$ š-ket ${ }_{9}$-te-e-ni DUMU.LÚ. ${ }_{19} \mathrm{LU}-m a \mathrm{x}[$

] $I^{!}$]-NA UD.2.KAM LI-IM $z a-a h-m i \mathrm{x}[$

]x pu-u-ri-aš-ma-aš píd-da-a-a[n-zi

]-ša le-e iš-ta-ma-[aš-te-ni 
49 A rev. 8

]-ri? na-at iš-ta-ma-a[š-te-en-? ] (empty)

A rev.

§ 10

50 A rev. 9 [

B rev. $1^{\prime}$

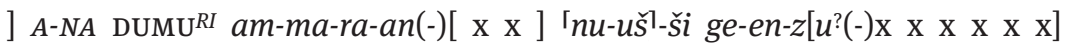
$n u-u s ̌-s ̌ i] ~\left[g e-e n-z u^{\top}\right.$ da-an-z[i? $\rightarrow$

51 A rev. 10 B rev. 1'f.

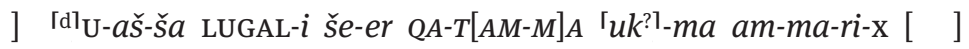
] / [dU]-aš-ša [LUGALl-i še-er QA-TAM-MA [

52 A rev. 11

B rev. $3^{\prime}$

[ QA-TA]M-MA da-la-* $a h^{*}$

-tén $[(. .)$.

C rev. $1^{\prime}$

$[n a-a] t^{?}-s ̌ i[$

$\mathrm{A}, \mathrm{B}$

\section{§ 11}


B rev. 4'-5' Гnu1 dUTU-uš dU-aš-ša $a$-aš-šu 'IGIHI.A-wa' [ ] / 'na'-aš-ta LUGAL-un MUNUS.LUGAL-an-na
C rev. $2^{\prime}-4^{\prime} \quad[$
]-tén / [
C after rev. $2^{\prime}$

「 $\left.a n^{?}-d a ?\right] \mathrm{x} \rightarrow$

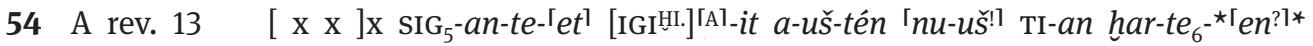

B rev. 5'-6' [ ] / 'a-ušl-tén nu-uš TI-an har-te-[en' $\rightarrow$

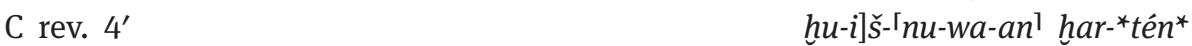

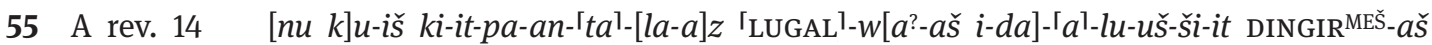

B rev. 6'-7' Гnu ku-iš [ ] / LUGAL-wa-aš i-da-a-lu-uš-ši-it DINGIR ${ }^{\mathrm{MES}}$-aš $\rightarrow$

C rev. $5^{\prime} \quad\left[\quad i\right.$-da-a-lu-uš]-[šil-it $\operatorname{DINGIR}^{\mathrm{MES}}$-aš

56 A rev. $15 \quad[p u]-\left[u^{1}-r i-i a-a s ̌-m a-a s ̌ ~ u ́-d a-[(a)-i \quad i]-\left[d a{ }^{\top}-a-l u\right.\right.$ ud-da-a-ar



C rev. 6' [ i-d]a-a-lu ut-tar $\rightarrow$

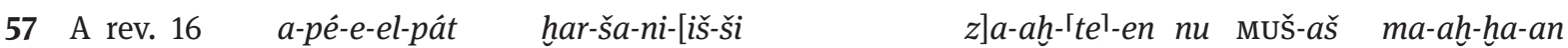

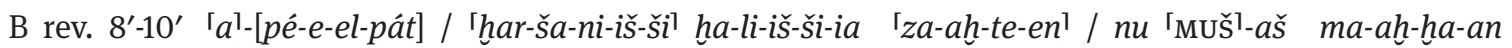

C rev. 6'-7' a-pé-el-pát huar-ša-ni-eš-ši / [ ma-ah-ha]-an

58 A rev. 17 ha-at-te-ěs-šar Ú-UL w[a?- u]t-Itar ${ }^{1}$ EGIR-pa a-pé-e-el-pát iš-ša-aš pa-id-du

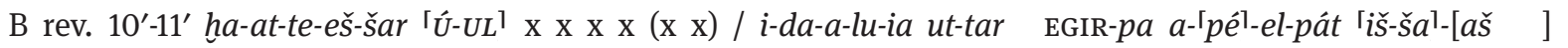

$\mathrm{C}$ rev. $7^{\prime}-8^{\prime} \quad$ ha-at-te-eš-šar / [ $\quad$ a-pé-e]l-pát iš-ša-aš pa-id-du

$\mathrm{A}, \mathrm{B}, \mathrm{C}$

\section{§ 12}

59 A rev. 18 ap-pé-ez-zi-iš-š $[a$

B rev. 12'-13' [a]p-pé-ez-zi-ša GIŠhu-u-ur-ki-iš ma-ah-hha-a[n

C rev. $9^{\prime} \quad[$

ha-an-te-e]z-zi-in GIšhur-ki-in

] / [GIš]hu-u-ur-ki-in

ha-an-te-ez-z]i-in GIšhur-ki-in ma-ah-ha-an

60 A rev. 19 Ú-UL ú-e-mi-[ial-[az-zi

ud-da-n]a-an-za

B rev. 13'-14' Ú-UL ú-e-mi-ia-az-z[i (ca. 4-6 signs) ] / [i]-da-a-lu-uš ud-da-a-na-an-za QA-TAM-M[A $\rightarrow$

C rev. $10^{\prime}$

$u d-d a-a-n] a-a n-z a$ 
61 A rev. 20 「le-e úl-[e-mi-ia-az-zi

B rev. $14^{\prime}-15^{\prime}$

C rev. $11^{\prime} \quad[$

] ' $u d-d a-a{ }^{\top}-a r$ AN.BAR-aš GIšIGAG-an'

] / [nu?] ka-a-ša DINGIRMEŠ-aš ud-da-a-ar A[N.BAR-aš ] $\rightarrow$

$u d-d a-a-a] r$ AN.BAR-aš GIšsaG-an

62
A rev. 21 [mahhan
]-it $n u$ ITU.GIBIL
B rev. $15^{\prime}-17^{\prime}$
-it nu Tru.GIBL
C rev. $12^{\prime}$
I]TU. ${ }^{[}$GIBIL $^{1}$

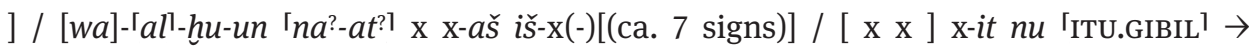

63
A rev. $22 \quad$ [
B lo.e. 17'-19' [ (ca. 9 signs) ] / [DINGIR $\left.{ }^{\mathrm{M}}\right]^{\mathrm{ES}}$ GAL.GAL DINGIR[MĚ
C rev. 13'

$k u-u t-r u]-{ }^{\top} e^{1}-e s ̌ a-s ̌ a-a n-d u$

(ca. 10 signs) ] / 「a $a$-ša-an-d[u $\rightarrow$

$k u-u] t-r u-\left[e^{1}-e s ̌ a-s ̌ a-a n-d u\right.$

63a B lo.e. $19^{\prime}-20^{\prime} \quad$ (ca. 12 signs) $] /\left[\begin{array}{l}\mathrm{x} \times \mathrm{x}\end{array}\right] a-[$

64
A rev. 23
dUTU-u]s
B le.e. 1
C rev. $14^{\prime}$
$\mathrm{d}_{\mathrm{U}-a s ̌-\check{a} a}$
${ }^{N A_{4}}{ } \mathrm{KIŠIB}$ DINGIR

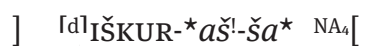
$-s \check{]} a$ ? $\mathrm{NA}_{4} \mathrm{KIŠIB}$ DINGIR

A rev. 24 (space for one line, but no signs remaining)

A

(remaining preserved surface in A uninscribed)

\section{Colophon}

65

B le.e. 2

]-Гre $e^{\mathrm{l}}-e z-z i \mathrm{QA-T}[\mathrm{I}]$

\section{Master Text: Transcription and Translation}

\$1

1

$[. .]=$. šan LUGAL-uš šarā $[. .$.

[...]-na paiš ezzašten [...]

[...] $\mathrm{x}(-)$ pišten eku[tten ...]

[ma]hhan=ma ITU.GIBIL ti[yazi ...]

[...]-waš eššari=šš $[i t$...]

\section{\$2}

$6 \quad[k]$ uwat=kan DINGIR ${ }^{\mathrm{MES}}$-iš LUGAL- $u s ̌$ ti-[...]



8 karpan harmi GIšišhauwar $=\check{S}(a) m i[t$...]

$9 \quad \bar{u} k$ harmi mimal=š(a)mit išpant [uzzi=šmit? ...]

10 anniškimi ANA DINGIR ${ }^{\mathrm{MES}}$ nahhhānza $\bar{u}[k$...]

11 tariyanz(a) ük nu memal NINDAh [aršin ...]

12 išpantuzziaš tariya $[n z(a)] \bar{u} k[\ldots]$

\section{\$3}

$13 n u=k a n$ DINGIR ${ }^{\text {MEŠšš }}$ anda aššuli nai $[\check{s}$...]

$14 n u=k a n$ kuit INA É-IA anda wašt [ul? ...]

$15 \quad[\mathrm{x}] \mathrm{x}[$ har?] ninkanz(a) waštahhun takku $a$-x-[...]

16 waštahhhun $[(\mathrm{x} x)]$ nu waštauš=muš [...] $\mathrm{x}-\mathrm{s}^{2}$ ? ēšta
$1[. .$.$] the king above upon [...] 2[...] he gave. You (pl.) eat!$ [...] ${ }^{3}$ You (pl.) give?! [You (pl.)] dri[nk! ...] ${ }^{4}$ When the new month be[gins ...] 5 his/her image of? [... ...].

6[W]hy, o gods, does the king (nom.) [...]? ${ }^{7} \mathrm{I}$ am one who makes every effort for you (pl.). The (wooden object) [...] ${ }^{8}$ I have lifted up. Your (pl.) drawbar? [...] 9I myself am holding. Your coarse meal (and) [your?] libati[on ...] ${ }^{10} \mathrm{I}$ perform. I amone who fears the gods. [fe.] br[ead ...] ${ }^{12}$ I am [one who] makes every e[ffort] for the libation [...].

${ }^{13} \mathrm{O}$ gods, $\mathrm{tu}[\mathrm{rn}]$ (to me) in favor [...] ${ }^{14}$ Because t[ransgression ...] into my house, [...] 15is [dest]royed?. I have transgressed. If [...] ${ }^{16 I}$ have sinned(?), and my sins (acc.) [...] it was. 


\section{\$4}

17

[...]x-tet uddanit

$18[. ..] \mathrm{x}{ }^{\mathrm{LU}} \mathrm{GAL}$ memiyanaz (C: ...]x-aiš)

19 (C: a]rha tittanut) [...] $\mathrm{DINGIR}^{\mathrm{MES}}$-iš waštauš=muš harnikten

\section{§5}

20

[...] x x [] x [...]-ēzzi

21

$[\ldots-n] a$ ŠEŠ-ŠU mun[na-? ... $n u=m u \quad A B U-I A]$ NU.GÁL $n u=m u$ AMA-IA NU.GÁL

22

$n u=m u$ šumeš $\mathrm{DINGIR}^{\mathrm{MEŠ}}-i \check{S} A B\left[U-I A^{?}\right.$... AMA $]-I A / i a$ dUTUŠI šumeš

23

$\bar{u} k k=a$ ÌR $^{\mathrm{MESS}}-\mathrm{KUNU}[. ..] \bar{u} k$

\section{$\$ 6$}

$a \bar{l}(\check{s})=s ̌ m i t$ DINGIR ${ }^{\mathrm{M}}\left[\mathrm{ES}_{-}-a \check{s}_{\text {.... }}\right]^{\mathrm{d}} \mathrm{UTU}-i{ }^{\mathrm{d}} \mathrm{U}-n i=y[a p] \bar{u} r i-$ $y a(\check{s})=\check{s} m a \check{s}$ piddānzi

\section{§7}

$[n=a] n$ kureškanz $\left[i\right.$... ]-kanzi ìn ${ }^{\mathrm{MES}}=m u[\check{S}] A P A L$ GUN!

$[$ hū $]$ rzakanzi $[\ldots=m]$ u EGIR ${ }^{\mathrm{NA}_{4}} \mathrm{ARA}_{5}$ ḩūrzakanzi

[...]-š=a lē ištamašteni duddu ${ }^{\mathrm{d}}$ ??][(...)]

[... lē iššs? attēni nu=šmaš=kan x LUGAL-i

[... ap?]panda lē ida[l]uš? [...]

[... idal]un EME-an lē išt[amašteni(?) ...]

[... l] $] \bar{e}$ iššatteni me-[...]

[... ]x LİM waštaš kuiš [...]

[... ]x munnaešketteni $n=u[\check{s}$...]

$[\ldots t] i$ yannešketteni kinuna $[. .$.

[...] $\mathrm{x} n=$ at munnatten $\mathrm{x}[. .$.

[...]x-nez $\check{S} A P A L \mathrm{DAM}^{\mathrm{MES}} \mathrm{da}-[. .$.

[... ha] rmikten

\section{\$8}

[...]X-eš/MEš? šumeš handante[š ...]

$43\left[. . . u\right.$ š̌kettēni DUMU.LÚ. U $_{19} \cdot \mathrm{LU}=\operatorname{ma} \mathrm{x}[\ldots]$

44 [...] INA UD.2.KAM LİM zahmi x[...]

$45[\ldots] \mathrm{x}$ pūria $(\check{s})=$ šmaš piddā $[n z i$.... $]$

$46[. .$.$] -ša lē ištama [$ šteni ...]
${ }^{17}[\ldots]$ your? [...] with a word ${ }^{18}[. .$.$] the supervisor through the$ matter (C: variant) ${ }^{19}[$.... $\mathrm{O}$ gods, eliminate my sins! (C: he took? [aw]ay?.)

${ }^{20}[\ldots]$... [...] ${ }^{21}$ his/her? brother con[ceal-?. I] (have) no [father]; I have no mother. ${ }^{22} Y o u, 0$ gods, are to me [my] $\mathrm{fa}[$ ther ...] and/my [mother]. You are (like) 'my majesty' (the king), ${ }^{23}$ and I am (like) your subjects.

${ }^{24}$ You alone, o gods, have placed kingship into my h[a]nd. ${ }^{25} \mathrm{All}$ the land is mine [and] I govern the [en]tire [popula]tion. ${ }^{26} \mathrm{He}$ (i.e. the slanderer) is one who neither $\mathrm{f}[\mathrm{ea}] \mathrm{rs}$ the gods nor fears [kings]hip?. ${ }^{27}$, however, will beat him, and I [will rem]ove? hi[m]. But these ${ }^{28}$ [set?] their evil mouth against me [to/before?] the god[s] (and) they bring (evil accusations) upon their lips to the Sun-god and to the Stormgod.

${ }^{29}$ They cut [hi]m off [...] they [(verb pres. pl. 3) ...]. The servants ${ }^{30}$ continually [cur]se ${ }^{29} \mathrm{me}$ (from) under (their) burden, $30[. .$.$] they continually curse me (from) behind$ the millstone. ${ }^{31}$ But do not listen [to them?]! Have Mercy, o [DN?! ... ${ }^{32}[$... do not d] o?/ma]ke? (imp. pl. 2). [...] them (acc.) to the king. ${ }^{33}[. .$.$] May an evil [...] not [... ba]ck?.$ [...] ${ }^{34}[. .$.$] Do not lis[ten] to the [evi]l tongue. [...] { }^{35}[. .$.$] Do$ not do/make (imp. pl. 2) [...] 36[...] thousand she/he has sinned. Who [... 37[...]... you (pl.) conceal (each). ${ }^{38[. . .] ~ y o u ~}$ enchant? each of ${ }^{37}$ th[em ...]. ${ }^{38} \mathrm{Now}$ [...] ${ }^{39}[. .$.$] conceal (imp.$ pl. 2) it! [...] ${ }^{40}[\ldots]$... among the wives ...[...]. ${ }^{41}[\ldots$ elim]inate (imp. pl. 2)! [(...)]

42[...] ... (pl.), you (pl.) just [gods? ...] ${ }^{43}[. .$.$] you (pl.) see. But$ the mortal [...] $44[. .$.$] On day two I will beat one thousand.$ [... ${ }^{45}[. ..] \mathrm{t}$ [hey] carry (evil accusations?) on their lips. [...] 46[...] but do not lis[ten (to them) ...] 


\section{\$9}

47

48

49

\section{§10}

50 [...] A-NA DUMU ${ }^{R I} \operatorname{ammaran(-)[\ldots ]~nu=šši~genzu~}$ $\operatorname{danz}[i ? \ldots]$

$51\left[. . .{ }^{\mathrm{d} U T U}-u \check{S}\right]{ }^{\mathrm{d} U} \mathrm{U}-a \check{S} \check{S}=a$ LUGAL-i šer $Q \bar{A} T A M M A u k ?=m a$ ammari-x[...]

52 $[n=a] t^{?}=\check{S} i[Q \bar{A} T A] M M A$ dalahten $[(. .)$.

\section{$\S 11$}

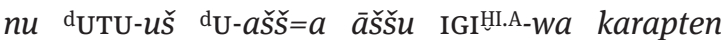
$n=a s ̌ t a$ LUGAL-un MUNUS.LUGAL- $a n n=a$ and $a$ ? [(...)]

$4[. ..] \mathrm{SIG}_{5}$-antet [IGI ${ }^{\mathrm{HI}}$.] $\left.{ }^{[\mathrm{A}}\right]_{-i t}$ aušten nu=uš [hui] šnuwan harten

5

nu kuiš kitpanta[la]z LUGAL-waš idālu=ššit DIN$\mathrm{GIR}^{\mathrm{MES}}$ - $a \check{S}^{-}$

56 pūriya $(\check{s})=\check{\text { šmaš }}$ uda[i] nu=ššan $\mathrm{DINGIR}^{\mathrm{MES}}$ - $a$ š idālu uddār

57 apēl=pat ḩaršani=šši hališšiya [z]ahten nu MUš-aš mahhan

58 hatteššar UL $w[a ?-. .$.$] \quad idālu=ya uttar EGIR-pa$ apēl=pat iššaš paiddu

\section{§12}

59 appezzišš = $a$ GIšhūrkiš mahhha[n haante]zzin GIŠhurkin

$60 U L$ wemiyazz[i ... i] dāluš uddānanza QĀTAMM[A

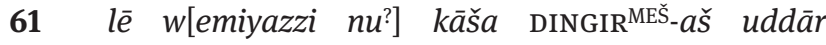

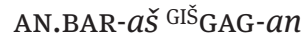

62 [mahhhan w]alhun $n^{?}=a t^{?} \times \mathrm{x}$-aš iš-x(-)[...]-it nu ITU. GIBIL [...]

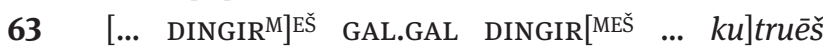
ašandu

$63 a \quad[. .] a-.[. .$.

$64\left[\ldots{ }^{\mathrm{d}} \mathrm{UTU}-u\right] \check{s}$ ? ${ }^{\mathrm{d}} \mathrm{U}-a \check{s ̌}^{5}=a{ }^{\mathrm{NA}_{4}} \mathrm{KIŠIB} \mathrm{DINGIR}$

\section{Colophon}

65

$$
\text { [... DUB ḩant?]ēzzi QA-T[I] }
$$

${ }^{47}[\ldots]$ the wor[ $[\mathrm{d}(\mathrm{s})$ ?] of that which is mutilated/cut up [...] ${ }^{48}[\ldots$ the $\mathrm{f}]$ oot?, the wor[ $\mathrm{d}(\mathrm{s})$ ?] of that which is cut off $[. .$. ${ }^{49}[. .$. do not?] list[en (2nd pl. imp.?)] to them! [...]

${ }^{50}[. .$.$] to the son/prince? ammaran(-)[...], and [they?] take$ pity on him. [...] 51[... the Sun-god] and the Storm-god for the sake of the king likewise (take pity on him). But I ... [...] ${ }_{52}[\ldots$ and in the sa]me way release (imp. pl. 2) him from $[i] \mathrm{t} ?[(\ldots)]$

${ }^{53}$ Now, O Sun-god and Storm-god, lift up kind eyes, and ${ }^{54}$ look ${ }^{53}$ upon the king and the queen in? [...] ${ }^{54}$ with kind [eye]s, and keep them alive! ${ }^{55-56} \mathrm{From}$ now on, who(ever) brings evil (intent/accusations) (against) the king on their lips to the gods, ${ }^{57}$ may you (pl.) strike on his very own head (and his) surroundings ${ }^{56}$ the evil words (brought) to the gods. As the snake ${ }^{58}$ does not [miss?] (its) hole, may the evil word also go back to the(ir) mouths.

${ }^{59} \mathrm{And}$ as the rear wheel ${ }^{60}$ does not catch up ${ }^{59}$ with the front wheel, ${ }^{60}$ in the same way may the evil word ${ }^{61}$ not find (the king). Herewith, ${ }^{62}$ have pounded ${ }^{61}$ the words to? the gods [like?] an iron peg, ${ }^{62}$ and it ... [...] The new month [...] ${ }^{63 t h e}$ great gods [...] may they be [wit]nesses. ${ }^{64}[. .$. the Sun-god?] and the Storm-god the divine seal [...].

65[Fi]rst? tablet. Compl[ete.]

Sun-goddess of Arinna (see also the fragmentary colophon of the same tablet; Archi 1988, 24 f.; Singer 2002a, 27).

3: Other possible interpretations of $] \mathrm{x}(-)$ pišten are the imp. pl. 2 forms of the verbs peš- "to rub" and karp- "to take up/away".

5: [...]-waš is most likely the genitive ending of a noun, possibly indicating the material of the statue. 
6: The variation between DINGIR ${ }^{\mathrm{MES}}$-eš in B and DIN-

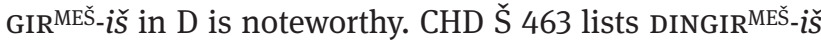
as a writing for both the pl. nom. and acc. com., but lists

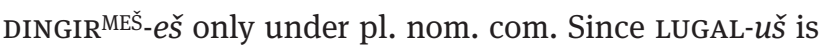
most likely the subject of the sentence, DINGIR ${ }^{\mathrm{MES}}$-eš/-iš must be understood as the nom. case for the vocative. Interestingly, the same writing is also used in B obv. 13 for the nom. pl. com., whereas A (obv. 6' and 9') uses DINGIR $^{M E S ̌}$-iš. On the declension of šiu-, see Hoffner/Melchert 2008, 100; Neu 1974, 122; ibid. 1998; Weeden 2011, 188193, as well as the entries in CHD and HEG.

The reading of the final sign of this line in $\mathrm{ms}$. D as ${ }^{[} t i^{1}$ follows Groddek (2006, 163).

7: HEG III, 171-174 lists two separate verbs under tariya-: I “anreden, anrufen (einen Gott)", and II "sich anstrengen, müde werden”. Kloekhorst (2008, 840 f.) lists a verb, dāriye/a-, of unknown meaning and for which he considers the translation "to call upon a god" to be uncertain. Many of the alleged attestations of dāriye/a-, however, are listed by Kloekhorst under the lemma tarai-/ tari- "to exert oneself, to become tired", including ta-riia-an-t-, due to the usual plene writing of $\bar{a}$ in dāriye/a(Kloekhorst 2008, 833-835). Both meanings are plausible in the present context, however the meaning "to exert" or similar (we have chosen the translation "to make every effort") has been preferred here due to its usage in line 12 (see below).

The fragmentarily preserved word determined by GIŠ most likely refers to some agricultural implement, if the interpretation of GIŠišhauwar in 1.8 as "drawbar?" (or similar) is correct (see commentary on this line).

8: GIšišhauwar is interpreted by Kloekhorst (2008, 392) as a "yoke-plough-set(?)" (from išhai- "to bind"); more specifically HW' IV, $140 \mathrm{f}$. ("wohl 'Deichsel, Pflugstange"”, i.e. "drawbar"). Thus, it seems that the king was also claiming to have contributed his own efforts to the field labor (certainly in a metaphorical or indirect sense) necessary to cultivate the grain used in the offerings to the gods.

11: Groddek $(2006,163)$ restores the final sign of the line in $\mathrm{D}$ as $w a$, and is thus probably thinking of ${ }^{\mathrm{NINA}}$ wagataš- or NINDAwageššar.

12: išpantuzziaš tariya $[\mathrm{nza}]$ is a genitive construction, the head noun of which is the participle sg. nom. of tarai-/ tari-, which occurred previously in lines 7 and 11 (see commentary on line 7). The participle is used here with an objective genitive, thus the meaning "to exert oneself, make every effort" (i.e., for the libation) is to be preferred here and elsewhere in this prayer.

14: Perhaps the MP verb iya- could be restored here: "Since sin entered into my house"; however, aside from uddar- "word", HW2 IV, 19-21 gives no other examples of an abstract noun used as the subject of MP iya-.

15: See 1. 19, where the verb harnink-also occurs in the context of eliminating transgressions.

16: Groddek $(2014,529)$ suggests ]x-še?, but the sign might instead be read as $-z]$, thus Lebrun (1980, 393). If the reading as $\check{s}$ is correct, this could be the enclitic sg. 3 pronoun or a verb form ending in ]-šešta.

17: Groddek $(2014,5)$ transliterates $-t]$ e-et in C obv. $5^{\prime}$, corresponding to the word preceding uddanit in $\mathrm{ms}$. A, thus Groddek restores uddanit at the beginning of $\mathrm{C}$ obv. $66^{\prime}$. Our translation of ]-tet as the sg. 2 nom.-acc. possessive suffix is tentative. This might instead be the instr. ending of a participle modifying uddanit. ${ }^{18}$ The preceding signs are incorrectly transliterated by Lebrun $(1980,393)$ as ] $\mathrm{x}$-aš ku-it.

18: Groddek (2014, 5 with n. 30) proposes the reading $-r] a-a$-iš in C obv. 6' (against the hand copy); note however the crevice in the tablet's surface running directly through the first vertical of the sign A here (hethiter.net/: PhotArch B1317g), raising the question of whether Groddek's "second" vertical might not after all belong to the sign A having only been displaced by the fissure in the tablet, as the copyist apparently understood it. Lebrun $(1980,393)$ misreads LUGAL.GAL in A obv. 5'.

19: The restoration of $a$ ] $r$-ha in ms. C follows Groddek $(2014,5)$ and is quite plausible here in the sense of "to take away, remove" (see attestations in HEG III, 386). Groddek restores the contents of A obv. $6^{\prime}$ in the line immediately following $\mathrm{C}$ obv. $7^{\prime}$ (not counted in the hand copy, given above in the transliteration as C obv. 7'a).

20: Collation of the 3D scan of ms. A allowed for no identification of the signs at the beginning of this line. Singer (2002a, 24) translates the verb ending with ]-ēzzi as "he holds".

21: The reading ' $m u-u n^{\top}$-[ is supported by collation of the 3D scan, and no other known Hittite word can be restored here except munnai-, which also appears in 11. 37

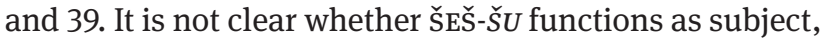
direct object or in the dat.-loc. (in case of the latter, restore perhaps $A-N] A$ ŠEŠ-ŠU). The transliteration by Lebrun (1980, 392), ]x LÚŠEŠ mu-x[, is incorrect.

22: DINGIR ${ }^{\mathrm{MES}} \mathrm{S}-i \check{S}$ either represents the younger pl. nom. form šiuniš, or is a younger variation of šiweš. Lebrun $(1980,393)$ reads šu-meš as a Sumerogram with plural determinative, ŠUMEŠ, but this makes no sense in the context.

22-23: Translation follows Singer (2002a, 24). Van den Hout $(1998,74)$ restores [ENMEŠ]-IA, thus his transla-

18 Theo van den Hout (personal communication). 
tion, "My Majesty’s [lords] (are) you and I, your servant(!?) am I". This is unlikely, since one would expect expressions parallel with "my father" (partially preserved) and also "my mother" (restored except for the possessive pronominal suffix). Lebrun $(1980,392)$ overlooks the sign $k a_{4}$, reading only $u$ u $u k$.

24: Collation of the 3D scan of ms. A confirms the reading of $[k i+$.

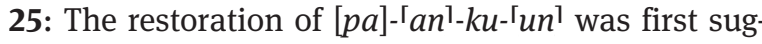
gested to me by D. Schwemer and confirmed by collation of the 3D scan, where the broken vertical of un (missing in the hand copy) is visible. Somewhat different the translation of Singer (2002a, 24): "Mine is the entire land and its [popula]tion and I govern it". We propose instead that [p]ankun belongs to a new sentence modifying the object of maniyahhiškemi, which Singer (2002a, 24) already restored as "[popula]tion", also followed in the present edition. The logogram [NAM.LÚ.U $19 . \mathrm{L}$ ] U should almost certainly be understood to represent antuhšătar (see Weeden 2011, 279-284), but, however, is surprisingly modified by a sg. com. acc. adjective.

26: DINGIR ${ }^{\mathrm{MES}}$ - $a s ̌$ is the pl. dat.-loc., and not a NH pl. gen., see CHD L-N 341. Restoration of [LUGAL-UT]-TI follows the translation by Singer (2002a, 24).

27: Restoration of [kar?]-ap- ${ }^{[} m i^{1}$ was suggested to me by D. Schwemer, and confirmed by the collation of the 3D scan; the signs $\mathrm{MI}$ and $\mathrm{A}$ are visible (against the hand copy with a sign similar to Ù followed by ZA).

28: A different transliteration of the beginning of this line is proposed by Lebrun (1980, 392), [ ]x TUR. Although the photo and the 3D scan confirm a space after the sign TUR, the following signs iš-mi-it cannot stand alone. The broader context provided by the adjoining fragments (not considered by Lebrun), however, necessitate our reading as ' $a$ l-i'-iš-mi-it (also read thus by HW' $\mathrm{HW}^{2}, 49 \mathrm{a}$ ), functioning as the nom.-acc. neut. direct object of a verb which is no longer preserved.

It is possible that a verb should be restored after

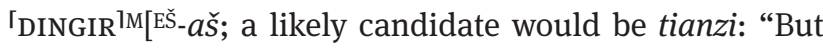
these [set] their evil mouth against (lit. upon) me [to/ before?] the gods". For the use of dai- with -ššan and an enclitic pronoun, compare the Hittite Laws (late version) §XXXVII, KBo 6.4 (OH/NS) iv 16-17 (cited in CHD Š 136) in the context of imposing šahhan upon someone. Therefore an expression, "to set something evil upon someone", seems plausible, as this would also metaphorically communicate personal responsibility for a particular matter, as is also the case with šahh̆an.

29: GUN! is incorrectly written as UZU.UN instead of GÚ.UN. The verb mareškanzi transliterated by Lebrun $(1980,392)$ does not exist.
30: An alternative restoration would be 'ak?1-kán-zi: "The servants are perishing under the burden"; the 3D scan does not support one reading over the other. However, the verb akk- would not make sense if the accusations against the king are indeed unjust, since the text would then implicitly indict the king here for burdening his subjects to the point of death. Given the parallelism of $\check{S} A P A L$ GUN and EGIR ${ }^{\mathrm{NA}_{4}} \mathrm{ARA}_{5}$, we propose that the same verb, hurzak- (-ške-form of huwart-/hurt-), occurs in both sentences, and in each case the enclitic -mu serves as the accusative direct object: "They continually curse me".

31: The imperative $d u d d u$ followed by a DN, seems more likely than a N.-A.n. participle dudduan, which HEG III, 479. 484 associates with *duddumi- "still; taub". The transliteration here by Lebrun $(1980,393)$ is incorrect.

32: Even though it is a bit small, the damaged sign before LUGAL $-i$ ? is most likely GIM. The head of a horizontal (left) and heads of two verticals (above and right) are visible on the tablet (confirmed by collations of the 3D scan). The context helps little since the verb is missing and there are two datives in the sentence: -šmaš, almost certainly referring to those who curse the king, and ILUGAL?-i? . Contextually, though, GIM would make sense, making a comparison between the king and his accusers which possibly continues into 1.33 . Thus the lines can be tentatively translated: "Just as to the king [...] the evil [...] shall not [return ...] (so also) to them [... (may something positive? not return?)]".

33: The nom. c. case ending -uš is confirmed by collation of the 3D scan.

36: Kloekhorst $(2008,985)$ only lists waštaš in his paradigm as pret. sg. 2 of wašta-, but in this context it must be understood as pret. sg. 3.

37: Collation of the 3D scan confirms the hand copy of the remains of the first preserved sign of this line, which could be restored as $\mathrm{K}] \mathrm{A} \times \mathrm{U}$.

38: tiyannešk- iterative from tiyaniya-, a verb attested in KUB 7.53 ii 10, 17 (ritual of Tunnawiya); in ibid. ii 12 the related verb tiyanišš- is also found, which Melchert $(1993,231)$ translates "fill, stuff" (following HW 224; see HEG III, 365 f.: "Verb u[nbekannter] B[edeutung], das die Auswirkung einer Behexung beschreibt”). Rieken (1999, 406 n. 2048) translates tiyaniya- in combination with ela/iniya- as "binden und schwächen".

40: ]x-ne-ez could be an ablative, or nom. c. of a dental stem. The plural determinative following DAM is incorrectly written as Eš; the fragmentary context offers no indication of who these wives might have been, but should be compared with the reference to "his brother" in 1. 21 . 
42: An interpretation of $T E^{\mathrm{MES} 19}$ at the end of this line is unlikely, since there is no space indicating word division between handan and these two signs, and the writing TE-MEŠ instead of te-eš is a frequent scribal error (see $e_{17}$ under HZL Nr. 360). ${ }^{20}$ Furthermore, a reference to oracles would be singular in the entire text composition. The signs are confirmed as TE-MEŠ by the 3D scan, thus

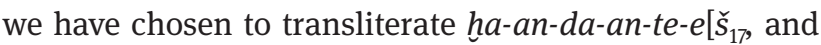
it seems here that the prayer addresses the "just gods". ${ }^{21}$

44: The remains of the first sign of this line seem to show a vertical wedge, rather than traces of the expected sign I, belonging to I-NA, which seems, however, to be the most likely word to have preceded UD.2.KAM.

45: The first sign of this line might be read as -i]t (supported by collation of the 3D scan), restore perhaps kui]t, thus, "whi]ch th[ey] carry on their lips".

48: The first sign is confirmed as Gìr by collation of the 3D scan.

50: Fragmentary am-ma-ra-an(-)[...] (reading confirmed by collation of the 3D scan) has no apparent connection to any other attested Hittite lexeme (see HW' ${ }^{2}$, 66b). The verb following genzu in B is certainly a form of $d a$ - "to take", see HED 4, 155 for other attestations of D.-L. + genzu da- "to take pity on someone". The only forms of $d a$ - written with initial $d a$-an-are pres. pl. 3 and the participle; the latter is possible, but pres. pl. 3 would very nicely parallel the plural subject of the following sentence (see below).

51: QA-TAM-MA should be understood as replacing genzu $d a$ - from the preceding sentence (see comment on 1. 50). A dat. enclitic pronoun probably stood at the beginning of this sentence, apparently referring again to the prince; it was upon him that the Sun-god and Storm-god were to take pity, namely "for the king's sake" (LUGAL- $i$ šer). am-ma-ri-x [...] could be a verbal form related to $\operatorname{ammaran}(-)[. .$.$] of line 50$. Incorrect transliteration here by Lebrun (1980, 394).

52: Although the hand copy of B implies the reading $[n u-u] \check{s}$-ši, the photo as well as context raise the possibility of reading $[n a-a] t$-ši, providing the expected direct object of the verb in addition to the indirect object (the sg. dat. enclitic pronoun -ši). Note that mss. A and B placed the paragraph marker one line earlier than in ms. C. Read tén at the end of the line, rather than hi (contra Lebrun 1980, 394).

19 For Akkadian têrtu, "liver oracles"; see Weeden 2011, 313 with n. 1458, and AHw III, 1350a.

20 Thanks to Theo van den Hout for pointing this out (personal communication).

21 Suggested by Theo van den Hout (personal communication).
53: The reading $\left[a n\right.$ ?- $d a$ ? ${ }^{\prime}$ in $\mathrm{B}$ rev. $5^{\prime}$ in the hand copy is unclear from the online photo (hethiter.net/: PhotArch BoFN06475).

54: The restoration of $\left[\mathrm{IGI}^{\mathrm{HI}}\right]^{[\mathrm{IAl}}$ follows van den Hout

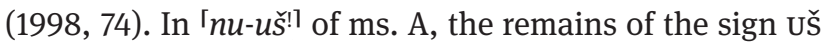
appear to be an anomalous form with a broken vertical (or remains of Winkelhaken or simply damaged surface above the head of an unbroken vertical; collated with the 3D scan). Lebrun $(1980,393)$ incorrectly transliterates $\mathrm{SIG}_{5}{ }^{-}$ an- -da-x[.

55: Although the combination LUGAL-waš idālu=ššit would normally indicate inalienable possession (Hoffner/ Melchert 2008, $251 \S 16.38$ ), even in OS texts there are instances where this is not the case (ibid. 251f. §16.39). A fitting example for comparison occurs in KUB 8.41 ii 7: LUGAL-aš MUNUS.LUGAL-š $=a$... papratar $=$ šamet.

57: For this reconstruction see Otten/Rüster (1974, 243) reflected in the translation of Singer (2002a, 25) and the transliteration of Groddek $(2006,164)$. hališšiya is normally a term of craftsmanship, referring to the inlaying or mounting of decorative objects, such as precious stones, or plating something (see HW2 III, 44-50); this meaning is carried over to the abstract sense of "surroundings".

Although the hand copy of ms. B gives no indication of the signs at the end of rev. 9, badly eroded traces of the verb $z a h t e n$ are indeed visible on the photo (hethiter.net/: PhotArch BoFN06475).

58: In A rev. 17, Otten/Rüster (1974, 245), Lebrun (1980, $394)$, and Groddek $(2006,164)$, all restore the sign $w[a$ - following $U$-UL. The traces of 4-6 signs in B rev. 10 are illegible (see photo: hethiter.net/: PhotArch BoFN06475). Singer (2002a, 25) tentatively translates here "miss?", which makes very good sense in this context. The verb could be transitive or intransitive, since although hatteššar occurs here in the sg. nom.-acc. neut., it could either serve as the direct object or as the accusative of direction. The verb wah-/weh- (or one of its derivations), could describe the winding movement of the snake. However, in this case one would expect the preverb arha to occur as well, i.e., the snake does not "wind away from" its hole. The verb watku- "to jump, to flee", should also be considered, but it too does not seem very likely without arha. Other possibilities include the verb wakk- or wakkišiya- "to be lacking" (Kloekhorst 2008, 940. 942), or the rarely attested waggašnu-, translated by Kloekhorst (2008, 942), as "to leave out", and to which the meaning "to overlook, pass over; to miss" would be quite similar.

A further difficulty in this line is posed by the noun iššaš: Hoffner (apud Singer 2002a, 287) proposed an emendation to $i \check{s} \check{s} a=\check{s} i$ "his mouth", which would, however, result in a redundancy with apēl, also meaning "his", and 
would require emending both mss. A and C. An alternative to this emendation would be to take iššaš as pl. dat.-loc. "to his mouths", where apēl refers to the evil word (idālu uttar) which was spoken by the mouths of those who had slandered the king.

59: Note that, unlike mss. A and B, in C rev. 9' mahhan is placed after the object rather than after the subject of the sentence.

60: The hand copy of ms. A implies the form ú-e-mi$e z$-[zi (see also Lebrun 1980, 393 and 394), but collation of the 3D scan confirms the sign at the break is in fact ia (two horizontals followed by at least two [likely three] horizontals and a vertical), and not Iz. The restoration of [LUGAL-Un MUNUS.LUGAL-an-na] at the end of B rev. 13, by Groddek $(2006,164)$ is quite probable; Ünal $(1996,63)$, however, restores EN.SISKUR, against which see Groddek (2006, 164 n. 74).

61-62: The heads of two remaining verticals of the sign AL in B rev. 16' are visible in the hand copy and on the photo, hethiter.net/: PhotArch BoFN06474, and correspond to the same sign occurring in B obv. 9, supporting the restoration of $[w]$ alhun. Compare the use of these terms in the literal sense in the Ritual of Hutuši. ${ }^{22}$ DINGIR $^{\text {MEŠs }}$-aš is understood in the dat. rather than the gen., since these are probably the words of slander spoken against the king to the gods, and not the words of the gods themselves. By means of the prayer and the accompanying rites (see especially 11. 1-12), these words are "pounded" into the ground, thus reversing their effects, as is often done with pegs in magical rituals (see Haas 2003, vol. 2, $734 \mathrm{f}$.); for further attestations of iron pegs, see also Košak (1983, 127 f.).

These lines have also been transliterated and translated by Weeden (2011, 310f.), whose reconstruction, however, allows for far too few missing signs at the beginning of each line. His restoration of [tar-ma-( $\left.\left.{ }^{\top} a{ }^{\top}\right)\right]$-it in line 62 (Weeden: 1. 13') is unlikely, since a similar thought is expressed in the $1^{\text {st }}$ person with the verb walh-, and it is not clear what verb should be restored here. His reading ITU-aš in KUB 43.68+ is incorrect (A ̌s is actually the lower vertical at the end of the sign ITU). On the reference to the new month, compare 1. 4. For restoration of the rest of $B$ rev. 16, see Groddek $(2006,164)$. The signs ITU.GIBIL in A rev. 21 are overlooked by Lebrun $(1980,394)$.

22 Thus in KUB 28.82 + KUB $9.11+$ KUB $28.63+$ IBoT 3.98 + Bo 4467 i 22-24 uk-t[u-u-ri]-ya-aš-ša-an AN.BAR pal-hi-- Išs $^{\top} k i-i t-t a$ (23) iš-tap$p[u-u] l-l i-i s ̌-s ̌ i-i t ~ s ̌ u-u-\left\ulcorner l i-y a^{1}-a s ̌ n ~ n a-a t-k a ́ n\right.$ iš-ta-a-pu (24) AN.BAR-aš$\check{s}[a]$-an tar-mu-uš wa-al-ha-a[n]-du "A vessel of iron lies upon the 'et[ern]al place'; its 1[i]d is of lead and (some)one should close it (i.e. the lid). They shall pound in the pegs of iron" (translation follows Siegelová 1984, 90).
64: The reading of the final signs of this line is debatable. Singer (2002a, 25) translates "[the seal of] the Stormgod and the seal [of the Sun-god(?)], implicitly recon-


This can almost certainly be ruled out, since elsewhere in this text, the name of the Storm-god follows that of the Sun-god (see 1l. 28, 51 [reconstructed] and 53). The reading of AN as a phonetic complement ( ${ }^{\left.{ }^{4} A_{4} \mathrm{KIŠI} I B-a n\right)}$ cannot be explained from the Hittite neuter noun *šiyatar, unless a common gender noun could also be represented by this logogram (see CHD Š 345a). One might consider the possibility that this is the neuter participle of šāi-/šiye- "to seal" followed by the pres. pl. 3 of hark- (space available in all duplicates). However, CHD Š $15 \mathrm{f}$. gives no attestations of a logographic writing of this verb. Rüster/Neu (1989, 141, Nr. 101), however, suggest the signs be read as $\mathrm{NA}_{4} \mathrm{MUL}$ "sternförmiger Stein?", a variation of the form of MUL with an unbroken vertical, while MUL is normally written with a broken vertical. Weeden (2011, 310 f.) prefers the reading ${ }^{\mathrm{NA}_{4} \mathrm{MUL}}$ and compares the concept of a star-shaped seal with the cruciform-seal of Muršili II. However, the only other attestation of the variant form of MUL (with an unbroken vertical) is allegedly found in HFAC 84:6 (Rüster/ Neu 1989, 141, Nr.101; Weeden 2011, 310). The hand copy of HFAC 84, however, clearly shows that MUL is written with a broken vertical and is determined with DINGIR, thus referring to a (deified) star. It therefore becomes questionable whether the variation of MUL with an unbroken vertical exists at all in the Hittite texts. The present text edition reflects the alternative (and normal) reading of ${ }^{{ }^{A} A_{4}} \mathrm{KIŠIB}_{\mathrm{I}}$ DINGIR "seal of the deity" (paralleled by the seals of deities in the treaties, e.g. in the Bronzetafel iv 44-45, see Otten 1988, 28 f.), although the collocation ${ }^{{ }^{N A} 4}{ }_{4} \mathrm{KIŠIB}$ DINGIR only occurs in the present text (see Weeden 2011, 311). In any case, both deity names should be understood as nominatives, rather than genitives of a head noun (thus, not as "seal of DN"), since in the latter case one would expect DUTU-wa-aš which cannot be reconciled with the broken sign at the beginning of A rev. 23.

65: Theoretically, the text could be restored here as app]ēzzi, "[Fin]al tablet". The context of the beginning of this tablet does not definitively rule out the possibility of (a) preceding tablet(s). 


\section{References}

Archi, A. (1988): Eine Anrufung der Sonnengöttin von Arinna, in: E. Neu/C. Rüster (eds.), Documentum Asiae Minoris Antiquae. Festschrift für Heinrich Otten zum 75. Geburtstag. Wiesbaden, 5-31

Collins, B. J. (1989): The representation of wild animals in Hittite texts. PhD thesis, Yale University, New Haven, Connecticut

Fisseler, D., et al. (2014): Extending philological research with methods of 3D computer graphics applied to analysis of cultural heritage, in: R. Klein/P. Santos (eds.), 12th Eurographics Workshop on Graphics and Cultural Heritage, 165-172

Görke, S. (ed.) (2006): hethiter.net/: CTH 443.1

- (ed.) (2012a): hethiter.net/: CTH 413.1

- (ed.) (2012b): hethiter.net/: CTH 414.1

Groddek, D. (2006): Hethitische Texte in Transkription: KUB 60. DBH 20. Wiesbaden

- (2014): Hethitische Texte in Transkription: KBo 59. DBH 44. Wiesbaden

Güterbock, H. G. (1974): Appendix: Hittite parallels, JNES 33, 323-327

Haas, V. (2003): Materia magica et medica hethitica. Ein Beitrag zur Heilkunde im Alten Orient. Berlin

Hoffner, H. A. (1963): The laws of the Hittites. PhD thesis, Graduate School of Arts and Sciences, Brandeis University, Waltham, Massachusetts

- (1997): The laws of the Hittites. A critical edition. DMOA 23. Leiden

Hoffner, H. A./H. C. Melchert (2008): A grammar of the Hittite language. Part 1: reference grammar. LANE 1. Winona Lake, Indiana

Hout, T. van den (1998): The purity of kingship. An edition of CTH 569 and related Hittite oracle inquiries of Tuthaliya IV. DMOA 25. Leiden; Boston; Köln

- (2007): The prayers in the Haus am Hang, in: D. Groddek/ M. Zorman (eds.), Tabularia Hethaeorum. Hethitologische Beiträge Silvin Košak zum 65. Geburtstag. DBH 25. Wiesbaden, 401-409

Hutter, M. (2012): Autobiographisches, Historiographisches und Erzählelemente in hethitischen "Gebeten" Arnuwandas und Mursilis, in: G. Wilhelm (ed.), Organization, Representation, and Symbols of Power in the Ancient Near East. Proceedings of the 54th Rencontre Assyriologique Internationale at Würzburg 20-25 July 2008. Winona Lake, Indiana, 665-673

Kassian, A. S. (2000): Two Middle Hittite rituals mentioning fZiplantawija, sister of the Hittite king mTuthalija II/I.

A. A. Korolëv (ed.). Moscow

Kellerman, G. (1980): Recherche sur les rituels de fondation hittites. Thèse présentée à l'Université de Paris - I en vue du doctorat de 3e cycle (specialité: histoire de l'antiquité), University of Paris

Klinger, J. (2005): Das Korpus der Kaškäer-Texte, AoF 32, 347-359

Kloekhorst, A. (2008): Etymological dictionary of the Hittite inherited lexicon. LIEEDS 5. Leiden

Košak, S. (1983): "The gospel of iron”, in: H. A. Hoffner/G. Beckman (eds.), Kaniššuwar: A tribute to Hans G. Güterbock on his seventy-fifth birthday. AS 23. Chicago, 125-135

Lebrun, R. (1980): Hymnes et Prières Hittites. Homo religiosus 4. Louvain-la-Neuve

Melchert, H. C. (1993): Cuneiform Luvian lexicon. Lexica Anatolica 2. Chapel Hill, North Carolina
Metcalf, C. (2011): New parallels in Hittite and Sumerian praise of the Sun, wO 41, 168-176

Miller, J. L. (2004): Studies in the origins, development and interpretation of the Kizzuwatna rituals. StBoT 46. Wiesbaden

Mouton, A. (ed.) (2012): hethiter.net/: CTH 404.1.III

Neu, E. (1974): Der Anitta-Text. StBoT 18. Wiesbaden

- (1983): Überlieferung und Datierung der Kaškäer-Verträge, in: R. M. Boehmer/H. Hauptmann (eds.), Beiträge zur Altertumskunde Kleinasiens. Mainz, vol. 1, 391-399

- (1998): Hethitisch ši-mu-uš, KZ 111, 55-60

Otten, H. (1988): Die Bronzetafel aus Boğazköy. Ein Staatsvertrag Tuthalijas IV. StBoT Beih. 1. Wiesbaden

Otten, H./C. Rüster (1974): Textanschlüsse und Duplikate von Boğazköy-Tafeln (31-40), ZA 64, 241-249

Rieken, E. (1999): Untersuchungen zur nominalen Stammbildung des Hethitischen. StBoT 44. Wiesbaden

Rüster, C./E. Neu (1989): Hethitisches Zeichenlexikon. Inventar und Interpretation der Keilschriftzeichen aus den Boğazköy-Texten. StBoT Beih. 2. Wiesbaden

Schuler, E. von (1965): Die Kaškäer. Ein Beitrag zur Ethnographie des alten Kleinasiens. UAVA 3. Berlin

Schwemer, D. (2006): Zwei hethitische Fragmente, AoF 33, 237-241

- (in press): Hittite prayers to the Sun-god for appeasing an angry personal god. A critical edition of CTH 372-74 (with a glossary and addendum by C. Steitler), in: M. Jaques (ed.), “Mon dieu, qu'ai-je donc fait ?" Les prières pénitentielles ( d in g i r - šà $\mathrm{d} a \mathrm{~b}-\mathrm{b} \mathrm{a})$ et l'expression de la piété privée en Mésopotamie. OBO (available at http://www.altorientalistik.uni-wuerzburg. de/fileadmin/ext00307/_temp_/CTH372_74_Vorpublikation. pdf)

Siegelová, J. (1984): Gewinnung und Verarbeitung von Eisen im Hethitischen Reich im 2. Jahrtausend v. u.Z., Annals Náprstek Museum 12, 71-168

Singer, I. (2002a): Hittite prayers. H. A. Hoffner (ed.). WAW 11. Leiden

- (2002b): Kantuzili the priest and the birth of Hittite personal prayer, in: P. Taracha (ed.), Silva Anatolica. Anatolian studies presented to Maciej Popko on the occasion of his 65th birthday. Warsaw, 301-313

Steitler, C. (2014): The solar deities of ancient Anatolia. A study of the Old and Middle Hittite texts. PhD thesis, Julius-Maximilians-Universität, Würzburg

Taracha, P. (2013): Political religion and religious policy: how the Hittite king chose his patron gods, AoF 40, 373-384

Ünal, A. (1996): The Hittite ritual of Hantitaššu from the city of Hurma against troublesome years. Publications of Turkish Historical Society VI/45. Ankara

Weeden, M. (2011): Hittite logograms and Hittite scholarship. StBoT 54. Wiesbaden 